\title{
Identification of a cDNA encoding a novel amphibian growth hormone-releasing peptide and localization of its transcript
}

\author{
K Sawada $^{1,2}$, K Ukena ${ }^{1,2}$, S Kikuyama ${ }^{3}$ and $\mathrm{K}_{\text {Tsutsui }}{ }^{1,2}$ \\ ${ }^{1}$ Laboratory of Brain Science, Faculty of Integrated Arts and Sciences, Hiroshima University, Higashi-Hiroshima 739-8521, Japan \\ ${ }^{2}$ Core Research of Evolutional Science and Technology (CREST), Japan Science and Technology Corporation, Tokyo 150-0002, Japan \\ ${ }^{3}$ Department of Biology, School of Education, Waseda University, Nishiwaseda 169-8050, Japan \\ (Requests for offprints should be addressed to K Tsutsui, Laboratory of Brain Science, Faculty of Integrated Arts and Sciences, Hiroshima University, \\ Higashi-Hiroshima 739-8521, Japan; Email: tsutsui@hiroshima-u.ac.jp)
}

\begin{abstract}
Recently, we identified in the bullfrog brain a novel neuropeptide with a C-terminal Leu-Pro-Leu-Arg-Phe$\mathrm{NH}_{2}$ sequence. This amphibian neuropeptide was shown to stimulate growth hormone $(\mathrm{GH})$ release in vitro and in vivo and so was designated frog GH-releasing peptide (fGRP). In this study, we cloned a cDNA encoding fGRP from the bullfrog brain by a combination of $3^{\prime}$ and $5^{\prime}$ rapid amplification of cDNA ends (RACE). The deduced fGRP precursor consisted of 221 amino acid residues, encoding one fGRP and three putative fGRP-related peptides that included Leu-Pro-Xaa-Arg-Phe- $\mathrm{NH}_{2}$ $(\mathrm{Xaa}=\mathrm{Leu}$ or Gln) at their C-termini. All these peptide
\end{abstract}

sequences were flanked by a glycine C-terminal amidation signal and a single basic amino acid on each end as an endoproteolytic site. Northern blot analysis detected a single band of approximately $1.0 \mathrm{~kb}$, indicating that no alternatively spliced forms were present. Such an apparent migration was in agreement with the estimated length of the cDNA, $902 \mathrm{bp}$. In situ hybridization further revealed the cellular localization of fGRP mRNA in the suprachiasmatic nucleus in the hypothalamus. In addition to fGRP, its related peptides may be hypothalamic factors involved in pituitary hormone secretion.

Journal of Endocrinology (2002) 174, 395-402

\section{Introduction}

It has been established that in a variety of vertebrates hypothalamic neurons produce neuropeptides, each regulating the secretion of a particular pituitary hormone. In amphibians, growth hormone $(\mathrm{GH})$ secretion from the somatotrophs is known to be under dual control: stimulatory and inhibitory. As stimulating factors, GH-releasing hormone (GHRH; for a review, see Montero et al. 2000), pituitary adenylate cyclase-activating polypeptide (PACAP; Martinez-Fuentes et al. 1994, Montero et al. 2000), and ghrelin (Kaiya et al. 2001) of amphibian origin have been nominated. As an inhibiting factor, frog somatostatin (Jeandel et al. 1998) has been described.

Since the molluscan neuropeptide Phe-Met-Arg-Phe$\mathrm{NH}_{2}$ (FMRFamide) was found in the ganglia of the venus clam (Price \& Greenberg 1977), immunohistochemical studies using the antiserum against FMRFamide have provided information that the vertebrate hypothalamus possesses some unknown neuropeptide similar to FMRFamide found in invertebrates. Recently, neuropeptides having the RFamide motif at their C-termini (RFamide peptides) have been identified in the brains of several vertebrates. For instance, Leu-Pro-Leu-Arg-Phe- $\mathrm{NH}_{2}$ (LPLRFamide), a chicken pentapeptide, was purified as the first RFamide peptide found in the vertebrate brain (Dockray et al. 1983). Two pain modulatory neuropeptides FF and AF (Yang et al. 1985), prolactin-releasing peptide (PrRP; Hinuma et al. 1998), and its fish counterpart, Carassius RFamide (Fujimoto et al. 1998), are also RFamide peptides. These RFamide peptides have been shown to play some important physiological roles in neuroendocrine, behavioral, sensory and autonomic functions (Panula et al. 1996, 1999, Ibata et al. 2000).

On the other hand, we previously identified SIKPSAYLPLRF- $\mathrm{NH}_{2}$, a novel hypothalamic RFamide peptide, which inhibited gonadotropin release in the quail and we termed this dodecapeptide gonadotropininhibitory hormone (GnIH; Tsutsui et al. 2000). Molecular cloning of cDNA encoding GnIH from the quail brain revealed that it encoded $\mathrm{GnIH}$ and its related peptides (GnIH-RP-1 and GnIH-RP-2), which contained a C-terminal LPXRF-NH $\mathrm{N}_{2}(\mathrm{X}=\mathrm{L}$ or $\mathrm{Q}$ ) sequence (Satake et al. 2001). The chicken pentapeptide LPLRFamide (Dockray et al. 1983) may be a fragment of GnIH (Satake et al. 2001). In addition, cDNAs encoding novel RFamide-related peptides (RFRPs) similar to GnIH were reported to exist in mammalian brains, based on the results of a gene database search (Hinuma et al. 2000), and the deduced RFRPs were suggested to participate in 
neuroendocrine (Hinuma et al. 2000) and pain mechanisms (Liu et al. 2001) in rodents. Two peptides have been predicted to be encoded in the cDNA of rodent RFRPs. Furthermore, we recently identified the octadecapeptide ANMEAGTMSHFPSLPQRF- $\mathrm{NH}_{2}$ as one of the rodent RFRPs (Ukena et al. 2002). In addition, a pentatriacontapeptide (SLTFEEVKDWAPKIKMNKPV VNKMPPSAANLPLRF- $\mathrm{NH}_{2}$ ) has been purified as one of the bovine RFRPs (Fukusumi et al. 2001). Collectively, these RFamide peptides identified in the brain of higher vertebrates are characterized by the LPXRFamide motif at their C-termini (LPXRFamide peptides).

In view of immunohistochemical findings indicating that some of the FMRFamide-like immunoreactive neurons project to the hypothalamic region close to the pituitary in amphibians (D'Aniello et al. 1996, Pinelli et al. 1999), we looked for a novel amphibian RFamide peptide existing in the bullfrog hypothalamus. As a result, a dodecapeptide, SLKPAANLPLRF- $\mathrm{NH}_{2}$ with a C-terminal LPLRFamide motif, was isolated (Koda et al. 2002). Interestingly, this peptide stimulated the release of $\mathrm{GH}$ from the bullfrog pituitary and was designated as frog GH-releasing peptide (fGRP; Koda et al. 2002). With these findings as a background, in the present study we sought and identified a cDNA encoding the fGRP precursor polypeptide as the next step to investigate further the physiological roles and biochemical characteristics of fGRP, which possibly contributes to the establishment of a novel regulatory system of $\mathrm{GH}$ release. Here we describe the fGRP cDNA sequence and the localization of the mRNA in the hypothalamus by in situ hybridization.

\section{Materials and Methods}

\section{$R N A$ preparation}

Adult bullfrogs (Rana catesbeiana) were used in this study. The experimental protocol was approved in accordance with the Guide for the Care and Use of Laboratory Animals prepared by Hiroshima University, Japan. Total RNA of the diencephalon was extracted by the guanidium thiocyanate-phenol-chloroform extraction method (Chomczynski \& Sacchi 1987), and the poly $(A)+$ RNA was then isolated with Oligotex-(dT) 30 (Daiichikagaku, Tokyo, Japan) in accordance with the manufacturer's instructions.

\section{Amplification of the partial fGRP $c D N A$ fragment}

All PCR amplifications were carried out in a reaction mixture containing Taq polymerase (Ex Taq polymerase (Takara Shuzo, Kyoto, Japan), PfuTurbo polymerase (STRATAGENE, La Jolla, CA, USA) or gene Taq polymerase (NIPPON GENE, Tokyo, Japan)) and $0 \cdot 2 \mathrm{mM}$ dNTP on a thermal cycler (Program Temp Control System PC-700, ASTEC, Fukuoka, Japan). First- strand cDNA was synthesized with the oligo (dT)-anchor primer supplied in the $5^{\prime} / 3^{\prime}$ rapid amplification of cDNA ends (RACE) kit (Roche Diagnostics, Basel, Switzerland) and amplified with the anchor primer (Roche Diagnostics) and the first degenerate primers $5^{\prime}-(\mathrm{T} / \mathrm{C}) \mathrm{TIAA}(\mathrm{A} / \mathrm{G})$ CCIGCIGCIAA(T/C)(T/C)TICC-3' (I represents inosine), corresponding to the fGRP sequence $\mathrm{Leu}^{2}-\mathrm{Lys}^{3}$ $\mathrm{Pro}^{4}-\mathrm{Ala}^{5}-\mathrm{Ala}^{6}-\mathrm{Asn}^{7}-\mathrm{Leu}^{8}-\mathrm{Pro}^{9}$ (Koda et al. 2002). Firstround PCR products were reamplified with the anchor primer and the second degenerate primers $5^{\prime}$-GCIAA (T/C)(T/C)TICCI(T/C)TI(C/A)GITT(T/C)GG-3', corresponding to the fGRP sequence $\mathrm{Ala}^{6}-\mathrm{Asn}^{7}-\mathrm{Leu}^{8}{ }^{8}$ Pro - Leu $^{10}-$ Arg $^{11}-\mathrm{Phe}^{12}-$ Gly $^{13}$ (Koda et al. 2002). Both first-round and second-round PCRs consisted of 30 cycles for $30 \mathrm{~s}$ at $94{ }^{\circ} \mathrm{C}, 30 \mathrm{~s}$ at $51{ }^{\circ} \mathrm{C}$, and $1 \mathrm{~min}$ at $72{ }^{\circ} \mathrm{C}$ (11 min for the last cycle). The second-round PCR products were subcloned into a TA-cloning vector in accordance with the manufacturer's instructions (Invitrogen, San Diego, CA, USA). The DNA inserts of the positive clones were amplified by PCR with universal M13 primers.

\section{Determination of the $5^{\prime}$-end sequence of $f G R P c D N A$}

Template cDNA was synthesized with an oligonucleotide primer complementary to nt 580-599 (5'-TTCAATTC TAGAGGATGGGA-3'); this synthesis was followed by dA-tailing of the cDNA with dATP and terminal transferase (Roche Diagnostics). The tailed cDNA was amplified with the oligo(dT)-anchor primer and gene-specific primer 1 (5'-GACTTTAGTCTTGCCAGACA-3', complementary to nt 428-447); this was followed by further amplification of the first-round PCR products with the anchor primer and gene-specific primer $2\left(5^{\prime}\right.$-GGGAAT GCTTTTGGCTATTT-3', complementary to nt 380399). Both first-round and second-round PCRs were performed for 35 cycles consisting of $1 \mathrm{~min}$ at $94{ }^{\circ} \mathrm{C}$, $1 \mathrm{~min}$ at $55^{\circ} \mathrm{C}$, and $1 \mathrm{~min}$ at $72{ }^{\circ} \mathrm{C}(11 \mathrm{~min}$ for the last cycle). The second-round PCR products were subcloned into a pPCR-Script Amp SK(+) cloning vector in accordance with the manufacturer's instructions (STRATAGENE), and the inserts were amplified as described above.

\section{DNA sequencing}

All nucleotide sequences were determined with an $\mathrm{ABI}$ PRISM Dye terminator cycle sequencing ready reaction kit (PE-Biosystems, Foster City, CA, USA) and a model 373A automated DNA sequencer (PE-Biosystems), and then analyzed with DNASIS-MAC software (Hitachi Software Engineering, Kanagawa, Japan). Universal M13 primers or gene-specific primers were used to sequence both strands. 
ATGAGTTGA

ATGCACTTGAAAATAGGCACATTGACTATAAGAACCATCATGCTTTTCACGCTTTGCACC 69 $\begin{array}{lllllllllllllllllllll}M & H & L & K & I & G & T & L & T & I & R & T & I & M & L & F & T & L & C & T & 20\end{array}$

TTCCTCACTCTTTTCGCCTTTTCCACCTGCTTTGATGAGACTAAAACAATCAATCTAGAA 129 $\begin{array}{lllllllllllllllllllll}\mathrm{F} & \mathrm{L} & \mathrm{T} & \mathrm{L} & \mathrm{F} & \mathrm{A} & \mathrm{F} & \mathrm{S} & \mathrm{T} & \mathrm{C} & \mathrm{F} & \mathrm{D} & \mathrm{E} & \mathrm{T} & \mathrm{K} & \mathrm{T} & \mathrm{I} & \mathrm{N} & \mathrm{L} & \mathrm{E} & \mathbf{4 0}\end{array}$ AGTCAAGAGATATATGATGACTTGTTTGAGTCCAAAGAAGATTTACAGAATGAGAGGAAT 189 $\begin{array}{lllllllllllllllllllll}S & Q & E & I & Y & D & D & L & F & E & S & K & E & D & L & Q & N & E & R & N & 60\end{array}$ GGTAATTCTGATGAGTATAGGTACATGGGATCCAACAGCATAAATGACATTAACAGATAC 249 $\begin{array}{lllllllllllllllllllll}G & N & S & D & E & Y & R & Y & M & G & S & N & S & I & N & D & I & N & R & Y & 80\end{array}$

AACAGACTGTCCATGCAGCCTGAGAACGAATTTCTACAGGAACGAAGCCTTAAACCTGCT 309 \begin{tabular}{lllllllllllllll|llllll}
$\mathrm{N}$ & $\mathrm{R}$ & $\mathrm{L}$ & $\mathrm{S}$ & $\mathrm{M}$ & $\mathrm{Q}$ & $\mathrm{P}$ & $\mathrm{E}$ & $\mathrm{N}$ & $\mathrm{E}$ & $\mathrm{F}$ & $\mathrm{L}$ & $\mathrm{Q}$ & $\mathrm{E}$ & $\mathrm{R}$ & $\mathbf{S}$ & $\mathrm{L}$ & $\mathbf{K}$ & $\mathbf{P}$ & $\mathbf{A}$ & 100
\end{tabular} fGRP

GCAAATCTGCCTCTGAGATTTGGAAGAACATCCGATGACAAAATAGCCAAAAGCATTCCC 369

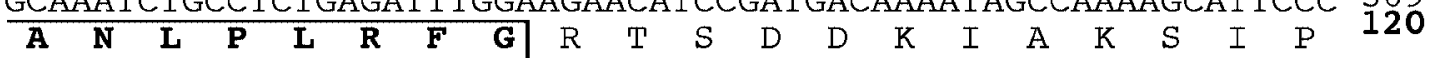

AGCTTTGATAAAATAGCCAAAAGCATTCCCAATCTACCGCAACGGTTTGGGCGTTACTTG 429

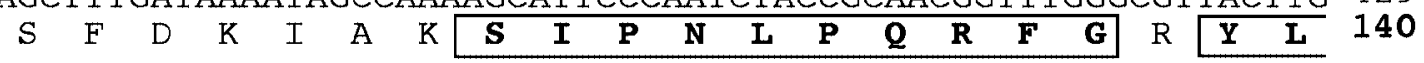
fGRP-RP-1

TCTGGCAAGACTAAAGTCCAGTCGATGGCTAATTTACCGCAGAGGTTTGGAAGAGCACAA 489 \begin{tabular}{llllllllllllllllll|llll}
\hline $\mathbf{S}$ & $\mathbf{G}$ & $\mathbf{K}$ & $\mathbf{T}$ & $\mathbf{K}$ & $\mathbf{V}$ & $\mathbf{Q}$ & $\mathbf{S}$ & $\mathbf{M}$ & $\mathbf{A}$ & $\mathbf{N}$ & $\mathbf{L}$ & $\mathbf{P}$ & $\mathbf{Q}$ & $\mathbf{R}$ & $\mathbf{F}$ & $\mathbf{G}$ & $\mathrm{R}$ & $\mathbf{A}$ & $\mathbf{Q}$ & 160 \\
\hline
\end{tabular} fGRP-RP-2

TATACCAACCATTTTGTTCACTCTCTTGATACATTACCACTGCGATTTGGAAGAACGCCG 549 \begin{tabular}{lllllllllllllllll|llllll}
$\mathbf{Y}$ & $\mathbf{T}$ & $\mathbf{N}$ & $\mathbf{H}$ & $\mathbf{F}$ & $\mathbf{V}$ & $\mathbf{H}$ & $\mathbf{S}$ & $\mathbf{L}$ & $\mathbf{D}$ & $\mathbf{T}$ & $\mathbf{L}$ & $\mathbf{P}$ & $\mathbf{L}$ & $\mathbf{R}$ & $\mathbf{F}$ & $\mathbf{G}$ & $\mathrm{R}$ & $\mathrm{T}$ & $\mathrm{P}$ & $\mathbf{1 8 0}$
\end{tabular} fGRP-RP-3

CATTCTGATAGACTTCAATATGAAATGAATTCCCATCCTCTAGAATTGAAAAACCCTGAA 609 $\begin{array}{lllllllllllllllllllll}\mathrm{H} & \mathrm{S} & \mathrm{D} & \mathrm{R} & \mathrm{L} & \mathrm{Q} & \mathrm{Y} & \mathrm{E} & \mathrm{M} & \mathrm{N} & \mathrm{S} & \mathrm{H} & \mathrm{P} & \mathrm{L} & \mathrm{E} & \mathrm{L} & \mathrm{K} & \mathrm{N} & \mathrm{P} & \mathrm{E} & \mathbf{2} \\ \end{array}$

GAAGACAGTGACAGGAAGAAAAGACAAGCAATGACCTTCCGAATACGAACGGATCTCCAG 669 $\begin{array}{lllllllllllllllllllll}\mathrm{E} & \mathrm{D} & \mathrm{S} & \mathrm{D} & \mathrm{R} & \mathrm{K} & \mathrm{K} & \mathrm{R} & \mathrm{Q} & \mathrm{A} & \mathrm{M} & \mathrm{T} & \mathrm{F} & \mathrm{R} & \mathrm{I} & \mathrm{R} & \mathrm{T} & \mathrm{D} & \mathrm{L} & \mathrm{Q} & \mathbf{2} 20\end{array}$ ATGTAGCAGCTAGTGAATCGCCCACAAAACCCATCATCTGTCCAACACTGTATTTCAAAC 729 $\mathrm{M} *$

AGCCAGATATGCACTCTTTGCACATAGTGGTGAAATCAGCTTTACGCTAATGCTTGACCC 789 ACTTTGAAATCAAAAGAAAAGTGATGAAAATGCAAAGCAAAGAAATGCATCAGAAAACTG 849 TGATGAAAACAATTATTTAGTTAAAGTACAACAAAACTACATTATTATACTGT-poly (A) 902

Figure 1 Nucleotide sequence and deduced amino acid sequence of frog GH-releasing peptide (fGRP) precursor polypeptide CDNA. The sequences of putative LPXRFamide peptides including fGRP are boxed. Putative precursor convertase (PC)-recognition sites of fGRP-RP-1, -2 and -3 are underlined. The asterisk indicates the stop codon. 


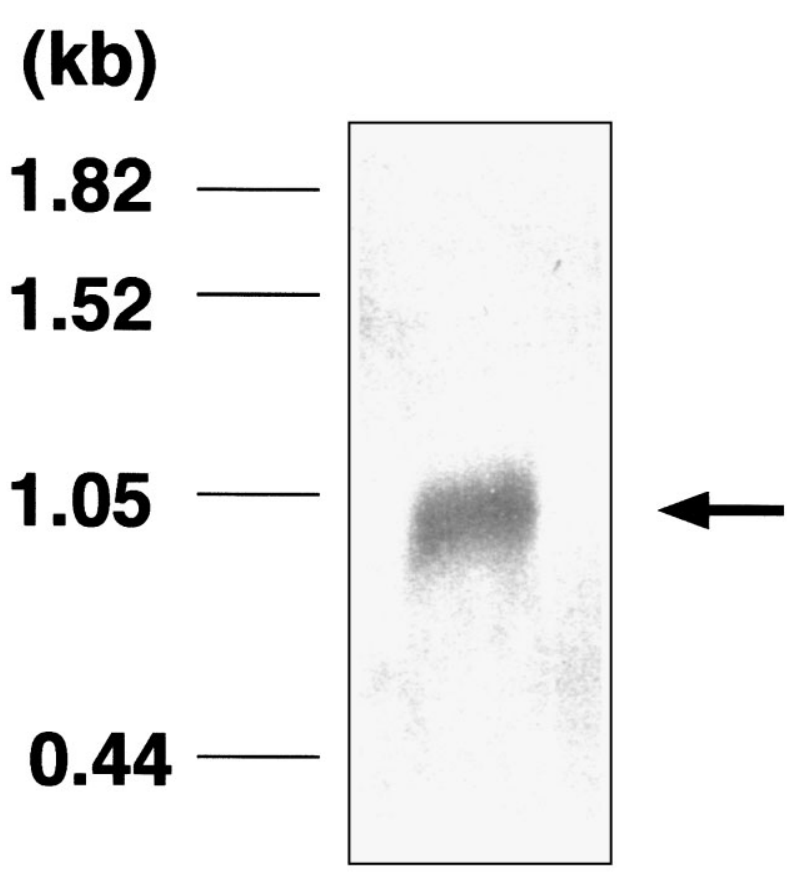

Figure 2 Size of the fGRP transcript. Northern blot analysis of mRNA prepared from the bullfrog brain. mRNA was purified from approximately $100 \mu \mathrm{g}$ total RNA and subjected to Northern blot hybridization with a DIG-labeled fGRP RNA probe. The single positive band is indicated by the arrow. The positions of RNA molecular mass markers are shown on the left.

\section{Northern blot analysis}

A digoxigenin (DIG)-labeled antisense RNA probe was produced with an RNA labeling kit (Roche Diagnostics) from a part of the fGRP precursor cDNA (complementary to nt 2-855, including all open reading frames) and used for Northern blot analysis. mRNA was separated on a denaturing $1 \%(\mathrm{w} / \mathrm{v})$ agarose/formaldehyde gel and fixed on a Hybond $\mathrm{N}+$ membrane (Amersham Pharmacia Life Science, Uppsala, Sweden) by u.v. irradiation. Hybridization and detection were performed in accordance with the manufacturer's standard procedure (Roche Diagnostics). RNA size was estimated with DIG-labeled RNA molecular markers (Roche Diagnostics).

\section{In situ hybridization of $f G R P m R N A$}

The site of fGRP mRNA expression in the brain was localized by in situ hybridization. In brief, adult bullfrogs were killed by decapitation. After dissection from the skull, the brains were fixed in $4 \%$ paraformaldehyde in PBS (pH 7.3) overnight at $4{ }^{\circ} \mathrm{C}$ and then soaked in a refrigerated sucrose solution (30\% sucrose in PBS) until they sank. Whole brains were embedded in OCT compound (Miles Inc., Elkhart, IN, USA) and freeze- sectioned frontally or sagittally at a $10 \mu \mathrm{m}$ thickness with a cryostat at $-20^{\circ} \mathrm{C}$. The sections were placed onto 3-aminopropyltriethoxysilane-coated slides. In situ hybridization was carried out according to our previous method (Ukena et al. 1999, Matsunaga et al. 2001) using the DIG-labeled antisense RNA probe, which was also used as a probe in the Northern blot hybridization.

Control for specificity of the in situ hybridization of fGRP mRNA was performed by using the DIGlabeled sense RNA probe, which was complementary to a common sequence of the antisense probe.

\section{Immunohistochemistry of $f G R P$}

Immunohistochemical analysis was performed as previously described (Koda et al. 2002). In brief, adult bullfrogs were killed by decapitation and the brains were fixed as described above. Frontal or sagittal sections (10 $\mu \mathrm{m}$ thickness) of the brain were made with a cryostat at $-20^{\circ} \mathrm{C}$. After nonspecific binding components had been blocked, the sections were immersed with the antiserum raised against fGRP (Koda et al. 2002) at a dilution of 1:1000 overnight at $4{ }^{\circ} \mathrm{C}$ and subsequently with rhodamine-conjugated goat anti-rabbit IgG. The localization of immunoreactive cell bodies and fibers in the bullfrog brain were examined with a Nikon fluorescence microscope. The specificity of the staining was assessed by substituting the antiserum with antiserum (1:1000 dilution) that had been preabsorbed with fGRP at a saturating concentration $(20 \mu \mathrm{g}$ synthetic fGRP/ml) overnight before use (see Koda et al. 2002).

\section{Results}

Characterization of $c D N A$ encoding $f G R P$ precursor polypeptide

In an attempt to obtain fGRP precursor polypeptide cDNA fragments from the bullfrog brain, we initially performed an RT-PCR experiment with degenerate primers corresponding to the partial fGRP sequence $\mathrm{Leu}^{2}-\mathrm{Lys}^{3}-\mathrm{Pro}^{4}-\mathrm{Ala}^{5}-\mathrm{Ala}^{6}-\mathrm{Asn}^{7}-\mathrm{Leu}^{8}-\mathrm{Pro}^{9}$ and the anchor primer, which was followed by reamplification of the first-round PCR products with degenerate primers corresponding to the partial fGRP sequence $\mathrm{Ala}^{6}-\mathrm{Asn}^{7}-$ $\mathrm{Leu}^{8}-\mathrm{Pro}^{9}-\mathrm{Leu}^{10}-\mathrm{Arg}^{11}-\mathrm{Phe}^{12}-\mathrm{Gly}^{13}$ and the same anchor primer. Here the $\mathrm{C}$-terminal amide group was thought to be derived from a C-terminal Gly residue, which is known to be a typical amidation signal (Bradbury et al. 1982, Suzuki et al. 1990, Eipper et al. 1991). Electrophoresis of the nested PCR mixture revealed a major product of approximately $0.65 \mathrm{~kb}$ (results not shown). The predicted amino acid sequence included three copies of the potential RFamide peptide sequence LPQRFG or LPLRFG downstream of the partial fGRP sequence derived 


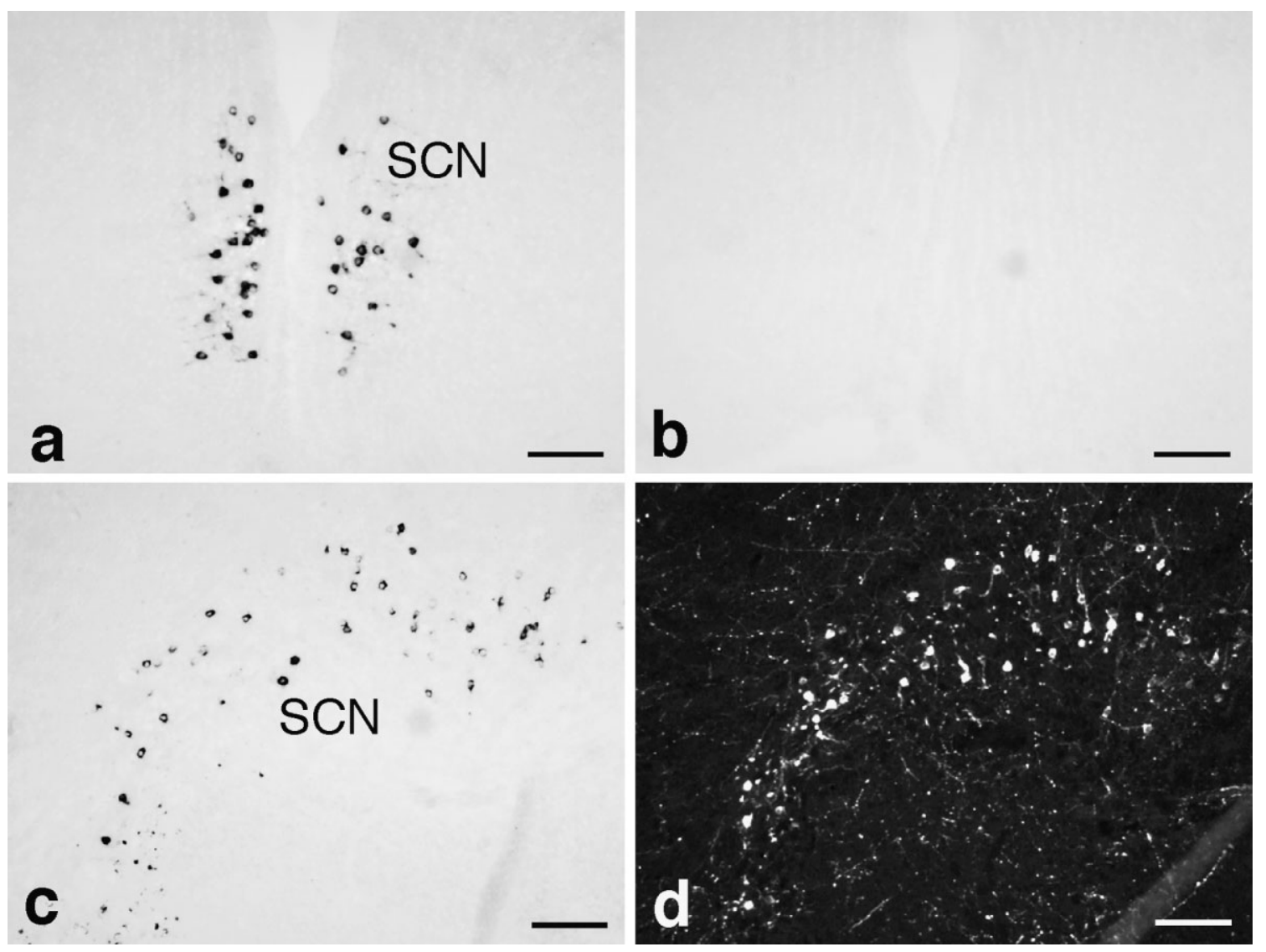

Figure 3 Cellular localization of fGRP mRNA in the brain. The expression of fGRP mRNA was localized by in situ hybridization. Distribution of fGRP mRNA in the suprachiasmatic nucleus (SCN) as observed in frontal (a) or sagittal (c) sections of the bullfrog brain. Lack of hybridization of fGRP mRNA by the sense probe (control) in a frontal section is evident (b). Immunohistochemical staining of a sagittal brain section (d) adjacent to that in (c) was carried out with antiserum against fGRP. Scale bars represent $100 \mu \mathrm{m}$.

from the second-round PCR primer, implying that this cDNA clone encoded also an RFamide peptide including a C-terminal sequence similar to that of fGRP $\left(\mathrm{LPLRF}-\mathrm{NH}_{2}\right.$ ). To determine whether the cDNA clones included also a fGRP sequence, we performed $5^{\prime}$ RACE with specific primers for the clone. A single product of approximately $0 \cdot 4 \mathrm{~kb}$ (results not shown) was obtained and sequenced, revealing that these cDNA clones contained a fGRP sequence. The entire fGRP precursor cDNA was identified by combining nucleotide sequences determined by these RACE experiments. Figure 1 shows that the deduced fGRP precursor encoded one fGRP and three putative gene-related peptide (fGRP-RP-1, -RP-2 and $-\mathrm{RP}-3)$ sequences that included $\mathrm{LPXRF}(\mathrm{X}=\mathrm{L}$ or $\mathrm{Q})$ at their C-termini. The fGRP precursor cDNA was composed of $902 \mathrm{nt}$ containing a short $5^{\prime}$ untranslated sequence of $9 \mathrm{bp}$, a single open reading frame of $663 \mathrm{bp}$, and a $3^{\prime}$ untranslated sequence of $230 \mathrm{bp}$ with a poly(A) tail of various lengths (Fig. 1). The open reading frame region began with a start codon at position 10 and terminated with a TAG stop codon at position 673 . The nucleotide sequence data reported will appear in DDBJ, EMBL and Gene Bank Nucleotide Sequence Databases under the accession number AB080743.

\section{Detection of $f G R P$ transcript in the frog brain}

Northern blot analysis of poly(A)+ RNA detected a single band of approximately $1.0 \mathrm{~kb}$ in the bullfrog brain (Fig. 2), indicating that no alternatively spliced forms were present. In addition, the apparent migration of approximately $1.0 \mathrm{~kb}$ was in good agreement with the estimated length of the cDNA, $902 \mathrm{bp}$. This result confirmed that the cDNA clone identified here included a full-length nucleotide sequence encoding the precursor of fGRP.

\section{Cellular localization of $f G R P m R N A$ in the frog brain}

In situ hybridization of fGRP $m R N A$ was examined in the bullfrog brain by using an RNA probe with a sequence 
Table 1 Sequences of frog GH-releasing peptide (fGRP), putative fGRP-related peptide (-RPs) and other identified LPXRFamide peptides

\begin{tabular}{|c|c|c|c|}
\hline & Animal & Name & Reference \\
\hline \multicolumn{4}{|l|}{ Sequence } \\
\hline SLTFEEVKDWAPKIKMNKPVVNKMPPSAANLPLRF-NH & Cow & RFRP-1 & Fukusumi et al. (2001) \\
\hline ANMEAGTMSHFPSL $\overline{\mathrm{PQRF}-\mathrm{NH}_{2}}$ & Rat & RFRP-2 & Ukena et al. (2002) \\
\hline SIKPSAYLPLRF-NH ${ }_{2}$ & Quail & GnlH & Tsutsui et al. (2000) \\
\hline SSIQSLLNLPQRF-NH & Quail & GnlH-RP-2 & Satake et al. (2001) \\
\hline SLKPAANLPLRF-NH & Bullfrog & fGRP & Koda et al. (2002) and this study \\
\hline SIPNL $\overline{P Q R F-N_{2}}$ & Bullfrog & fGRP-RP-1 & This study \\
\hline YLSGKTKVQSMANLPQRF-NH & Bullfrog & fGRP-RP-2 & This study \\
\hline AQYTNHFVHSLDTLPLRF-NH & Bullfrog & fGRP-RP-3 & This study \\
\hline
\end{tabular}

complementary to that of the fGRP precursor mRNA. Expression was finally detected by enzyme immunohistochemistry. An intense expression of fGRP mRNA was detected only in the suprachiasmatic nucleus (SCN) in the hypothalamus (Fig. 3a and c). The control study using the sense RNA probe resulted in the complete absence of the fGRP mRNA expression in the SCN (Fig. 3b), suggesting that the reaction was specific for fGRP mRNA. Furthermore, the SCN cells expressing fGRP mRNA (Fig. 3c) were also stained by the antiserum raised against fGRP (Fig. 3d). A complete absence of such an immunoreaction in the SCN cells was observed by preincubation of the antiserum with synthetic fGRP (data not shown; see Koda et al. 2002).

\section{Discussion}

Recently, we identified a novel hypothalamic neuropeptide stimulating GH release from the bullfrog pituitary in vitro and in vivo, and therefore designated it fGRP (Koda et al. 2002). This peptide was characterized by a structure including the C-terminal LPLRF-NH $\mathrm{N}_{2}$ motif (Koda et al. 2002). In the present study, we determined the fGRP cDNA sequence and the localization of the transcript in the bullfrog brain as the next step. We first identified a cDNA encoding fGRP from the bullfrog brain by a combination of $3^{\prime}$ and $5^{\prime}$ RACE. We predicted that the fGRP transcript would be translated with $\mathrm{Met}^{1}$, because a hydropathy plot analysis of the fGRP precursor demonstrated that the most hydrophobic moiety, which is typical in a signal peptide region, followed $\mathrm{Met}^{1}$. The cleavage site of the signal peptide was the $\mathrm{Phe}^{25}-\mathrm{Ala}^{26}$ bond. The deduced precursor polypeptide consisted of 221 amino acid residues, encoding one fGRP and three putative gene-related peptide sequences, i.e. fGRP-RP-1, -2 and -3 (Fig. 1). All four peptides shared the C-terminal sequence LPXRF motif (with $\mathrm{X}$ representing $\mathrm{L}$ in fGRP and fGRP-RP-3, and $Q$ in fGRP-RP-1 and fGRP-RP-2). In the frog, it has been demonstrated that the proprotein convertases PC1 and PC2, which are responsible for the processing of neuropeptide precursors, are abundantly expressed in the brain including the hypothalamus (Vieau et al. 1998, Gangnon et al. 1999). Several proprotein convertases (PCs) are usually considered to recognize and cleave a precursor polypeptide at the Lys/Arg-(Xaa) $n$-Lys/Arg sequence $(n=0,2,4$ or 6 ; reviewed in Seidah \& Chrétien 1999). Their sequences of putative fGRP-RP-1, -2 and -3 are flanked on both ends by the typical endoproteolytic sequences, i.e. KIAK or RFGR (Fig. 1), suggesting that mature peptides may be generated. Although fGRP (SLKPAANLPLRF-NH ${ }_{2}$ ) purified previously has the cleavage sequences of RSLK and RFGR in the precursor polypeptide, the N-terminal cleavage does not occur between Lys and Pro (Fig. 1). Therefore, some other $\mathrm{N}$-terminal processing mechanism(s) may be present in this precursor polypeptide. On the other hand, Gly preceding the C-terminal cleavage site may serve as a C-terminal amidation signal (Bradbury et al. 1982, Suzuki et al. 1990, Eipper et al. 1991). Future study is required to characterize mature endogenous fGRP-RPs by mass spectrometric analysis and clarify their biological functions.

Identification of the cells expressing fGRP mRNA in the brain must be taken into account when studying the action of neuropeptides. In the present study, we therefore characterized the site showing the expression of fGRP mRNA by in situ hybridization. The fGRP mRNA expression was localized in the SCN in the bullfrog hypothalamus. The control study using a sense RNA probe resulted in a complete absence of the fGRP mRNA expression, suggesting the validity of the in situ hybridization technique. In our previous study (Koda et al. 2002), the cell bodies and terminals containing fGRP were localized immunohistochemically in the SCN and median eminence (ME) respectively. It was demonstrated earlier that the frog ME receives innervation from SCN neurons (Carr et al. 1991, D'Aniello et al. 1996). Thus the present results obtained by in situ hybridization analysis are in agreement with the previous immunohistochemical findings (Koda et al. 2002). Taken together, it is possible that fGRP acts as an endogenous ligand in the bullfrog hypothalamo-hypophysial system. Although immunoreactive cell bodies were found not only in the SCN but 
also in the anterior preoptic area (POA) and medial septal area (MSA; Koda et al. 2002), we detected the fGRP mRNA signal only in the SCN. It may be that the expression level of fGRP mRNA in the POA and MSA was too low to detect the signal in these brain regions with the present in situ hybridization or that some other undiscovered peptide(s) that cross-reacts with the antiserum against fGRP exists in the POA and MSA. Notwithstanding such discrepancy in the POA and MSA, many neuropeptides, such as thyrotropin-releasing hormone, galanin, PACAP, and somatostatin are known to be expressed in the SCN of the frog (Lamacz et al. 1989, Laquerrière et al. 1989, Lázár et al. 1991, Yon et al. 1992). We need to elucidate the co-localization of fGRP/fGRPRPs and these neuropeptides and their interaction in the frog SCN.

We recently identified novel hypothalamic neuropeptides containing a C-terminal LPXRF- $\mathrm{NH}_{2}$ sequence (LPXRFamide peptides) in the avian and amphibian species: GnIH (SIKPSAYLPLRF-NH ${ }_{2}$ ) and its related peptide GnIH-RP-2 (SSIQSLLNLPQRF-NH ${ }_{2}$ ) in the quail (Tsutsui et al. 2000, Satake et al. 2001) and fGRP (SLKPAANLPLRF-NH ${ }_{2}$ ) in the bullfrog (Koda et al. 2002). In addition, similar neuropeptides RFRPs were identified in mammals: RFRP-1 (SLTFEEVKDWAPKI KMNKPVVNKMPPSAANLPLRF- $\mathrm{NH}_{2}$ ) in the bovine (Fukusumi et al. 2001) and RFRP-2 (ANMEAGTMS HFPSLPQRF-NH $\mathrm{N}_{2}$ ) in the rat (Ukena et al. 2002). As summarized in Table 1, all of the identified neuropeptides are LPXRFamide peptides. fGRP-RPs are also LPXRFamide peptides (Table 1). The present study suggests that fGRP-RPs as well as fGRP may be involved in the regulation of secretion of $\mathrm{GH}$ and other pituitary hormones in the bullfrog. The mammalian RFRP has been suggested to regulate prolactin secretion (Hinuma et al. 2000). Therefore, the presence of LPXRFamide peptides regulating pituitary hormone secretion may be a conserved property of the vertebrate brain. To draw a firm conclusion, we are now conducting studies on fish.

\section{Acknowledgements}

This work was supported in part by Grants-in-Aid for Scientific Research from the Ministry of Education, Science and Culture, Japan (11170237, 11354010, 12440233, 12894021, 13210101 (KT), and 12440234 (SK)) and the SUNBOR GRANT from Suntory Institute for Bioorganic Research, Osaka, Japan (KU).

\section{References}

Bradbury AF, Finnie MD \& Smyth DG 1982 Mechanism of C-terminal amide formation by pituitary enzymes. Nature $\mathbf{2 9 8}$ 686-688.
Carr JA, Norris DO \& Samora A 1991 Organization of tyrosine hydroxylase-immunoreactive neurons in the di- and mesencephalon of the American bullfrog (Rana catesbeiana) during metamorphosis. Cell and Tissue Research 263 155-163.

Chomczynski P \& Sacchi N 1987 Single-step method of RNA isolation by acid guanidinium thiocyanate-phenol-chloroform extraction. Analytical Biochemistry 162 156-159.

D'Aniello B, Vallarino M, Pinelli C, Fiorentino M \& Rastogi RK 1996 Neuropeptide Y: localization in the brain and pituitary of the developing frog (Rana esculenta). Cell and Tissue Research $\mathbf{2 8 5}$ 253-259.

Dockray GJ, Reeve JR Jr, Shively J, Gayton RJ \& Barnard CS 1983 A novel active pentapeptide from chicken brain identified by antibodies to FMRFamide. Nature 305 328-330.

Eipper BA, Perkins SN, Husten EJ, Johnson RC, Keutmann HT \& Mains RE 1991 Peptidyl $\alpha$-hydroxyglycine $\alpha$-amidating lyase. Journal of Biological Chemistry 266 7827-7833.

Fujimoto M, Takeshita K, Wang X, Takabatake I, Fujisawa Y, Teranishi H, Ohtani M, Muneoka Y \& Ohta S 1998 Isolation and characterization of a novel bioactive peptide, Carassius RFamide (C-RFa), from the brain of the Japanese crusian carp. Biochemical and Biophysical Research Communications 242 436-440.

Fukusumi S, Habata Y, Yoshida H, Iijima N, Kawamata Y, Hosoya M, Fujii R, Hinuma S, Kitada C, Shintani Y, Suenaga M, Onda H, Nishimura O, Tanaka M, Ibata Y \& Fujino M 2001 Characteristics and distribution of endogenous RFamide-related peptide-1. Biochimica et Biophysica Acta 1540 221-232.

Gangnon F, Danger JM, Jegou S, Vieau D, Seidah NG \& Vaudry H 1999 Molecular cloning, characterization of cDNA, and distribution of mRNA encoding the frog prohormone convertase PC1. Journal of Comparative Neurology 405 160-172.

Hinuma S, Habata Y, Fujii R, Kawamata Y, Hosoya M, Fukusumi S, Kitada C, Masuo Y, Asano T, Matsumoto H, Sekiguchi M, Kurokawa T, Nishimura O, Onda H \& Fujino M 1998 A prolactin-releasing peptide in the brain. Nature 393 272-276.

Hinuma S, Shintani Y, Fukusumi S, Iijima N, Matsumoto Y, Hosoya M, Fujii R, Watanabe T, Kikuchi K, Terao Y, Yano T, Yamamoto T, Kawamata Y, Habata Y, Asada M, Kitada C, Kurokawa T, Onda H, Nishimura O, Tanaka M, Ibata Y \& Fujino M 2000 New neuropeptides containing carboxy-terminal RFamide and their receptor in mammals. Nature Cell Biology 2 703-708.

Ibata Y, Iijima N, Kataoka Y, Kakihara K, Tanaka M, Hosoya M \& Hinuma S 2000 Morphological survey of prolactin-releasing peptide and its receptor with special reference to their functional roles in the brain. Neuroscience Research 38 223-230.

Jeandel L, Okuno A, Kobayashi T, Kikuyama S, Tostivint H, Lihrmann I, Chartrel N, Conlon JM, Fournier A, Tonon MC \& Vaudry H 1998 Effects of the two somatostatin variants somatostatin-14 and [Pro2, Met13] somatostatin-14 on receptor binding, adenylyl cyclase activity and growth hormone release from the frog pituitary. Journal of Neuroendocrinology 10 187-192.

Kaiya H, Kojima M, Hosoda H, Koda A, Yamamoto K, Kitajima Y, Matsumoto M, Minamitake Y, Kikuyama S \& Kangawa K 2001 Bullfrog ghrelin is modified by $n$-octanoic acid at its third threonine residue. Journal of Biological Chemistry 276 40441-40448.

Koda A, Ukena K, Teranishi H, Ohta S, Yamamoto K, Kikuyama S \& Tsutsui K 2002 A novel amphibian hypothalamic neuropeptide: isolation, localization and biological activity. Endocrinology 143 411-419.

Lamacz M, Hindelang C, Tonon MC, Vaudry H \& Stoeckel ME 1989 Three distinct thyrotropin-releasing hormone-immunoreactive axonal systems project in the median eminence-pituitary complex of the frog Rana ridibunda. Immunocytochemical evidence for co-localization of thyrotropin-releasing hormone and mesotocin in fibers innervating pars intermedia cells. Neuroscience 32 451-462.

Laquerrière A, Leroux P, Gonzalez BJ, Bodenant C, Benoit R \& Vaudry H 1989 Distribution of somatostatin receptors in the brain 
of the frog Rana ridibunda: correlation with the localization of somatostatin-containing neurons. Journal of Comparative Neurology 280 451-467.

Lázár GY, Liposits ZS, Tóth P, Trasti SL, Maderdrut JL \& Merchenthaler I 1991 Distribution of galanin-like immunoreactivity in the brain of Rana esculenta and Xenopus laevis. Journal of Comparative Neurology 310 45-67.

Liu Q, Guan XM, Martin WJ, McDonald TP, Clements MK, Jiang Q, Zeng Z, Jacobson M, Williams DL Jr, Yu H, Bomford D, Figueroa D, Mallee J, Wang R, Evans J, Gould R \& Austin CP 2001 Identification and characterization of novel mammalian neuropeptide FF-like peptides that attenuate morphine-induced antinociception. Journal of Biological Chemistry 40 36961-36969.

Martinez-Fuentes AJ, Gonzalez de Aguilar JL, Lacuisse S, Kikuyama S, Vaudry H \& Gracia-Navarro F 1994 Effect of frog pituitary adenylate cyclase-activating polypeptide (PACAP) on amphibian pituitary cells. In Vasoactive Intestinal Peptide, Pituitary Adenylate Cyclase-Activating Polypeptide and Related Regulatory Peptides: from Molecular Biology to Clinical Applications, pp 376-380. Ed. G Rosselin. Singapore: World Scientific.

Matsunaga M, Ukena K \& Tsutsui K 2001 Expression and localization of cytochrome P450 17 $\alpha$-hydroxylase/c17,20-lyase in the avian brain. Brain Research 899 112-122.

Montero M, Yon L, Kikuyama S, Dufour S \& Vaudry H 2000 Molecular evolution of the growth hormone-releasing hormone/pituitary adenylate cyclase-activating polypeptide gene family. Functional implication in the regulation of growth hormone secretion. Journal of Molecular Endocrinology 25 157-168.

Panula P, Aarnisalo AA \& Wasowicz K 1996 Neuropeptide FF, a mammalian neuropeptide with multiple functions. Progress in Neurobiology 48 461-487.

Panula P, Kalso E, Nieminen M, Kontinen VK, Brandt A \& Pertovaara A 1999 Neuropeptide FF and modulation of pain. Brain Research 848 191-196.

Pinelli C, D'Aniello B, Fiorentino M, Calace P, Di Meglio M, Iela L, Meyer DL, Bagnara JT \& Rastogi RK 1999 Distribution of FMRFamide-like immunoreactivity in the amphibian brain: comparative analysis. Journal of Comparative Neurology 414 274-305.

Price DA \& Greenberg MJ 1977 Structure of a molluscan cardioexcitatory neuropeptide. Science 197 670-671.
Satake H, Hisada M, Kawada T, Minakata H, Ukena K \& Tsutsui K 2001 Characterization of a cDNA encoding a novel avian hypothalamic neuropeptide exerting an inhibitory effect on gonadotropin release. Biochemical Journal 354 379-385.

Seidah NG \& Chrétien M 1999 Proprotein and prohormone convertases: a family of subtilases generating diverse bioactive polypeptides. Brain Research 848 45-62.

Suzuki K, Shimoi H, Iwasaki Y, Kawahara T, Matsuura Y \& Nishikawa Y 1990 Elucidation of amidating reaction mechanism by frog amidating enzyme, peptidylglycine $\alpha$-hydroxylating monooxygenase, expressed in insect cell culture. EMBO Journal 9 4259-4265.

Tsutsui K, Saigoh E, Ukena K, Teranishi H, Fujisawa Y, Kikuchi M, Ishii S \& Peter JS 2000 A novel avian hypothalamic peptide inhibiting gonadotropin release. Biochemical and Biophysical Research Communications 275 661-667.

Ukena K, Kohchi C \& Tsutsui K 1999 Expression and activity of $3 \beta$-hydroxysteroid dehydrogenase $/ \Delta^{5}-\Delta^{4}$-isomerase in the rat Purkinje neuron during neonatal life. Endocrinology 140 805-813.

Ukena K, Iwakoshi E, Minakata H \& Tsutsui K 2002 A novel rat hypothalamic RFamide-related peptide identified by immunoaffinity chromatography and mass spectrometry. FEBS Letters 512 255-258.

Vieau D, Gangnon F, Jégou S, Danger JM \& Vaudry H 1998 Characterization of the cDNA encoding the prohormone convertase PC2 and localization of the mRNA in the brain of the frog Rana ridibunda. Molecular Brain Research 63 1-13.

Yang H-YT, Fratta W \& Majane EA 1985 Isolation, sequencing, synthesis, and pharmacological characterization of two brain neuropeptides that modulate the action of morphine. PNAS $\mathbf{8 2}$ 7757-7761.

Yon L, Feuilloley M, Chartrel N, Arimura A, Conlon JM, Fournier A \& Vaudry H 1992 Immunohistochemical distribution and biological activity of pituitary adenylate cyclase-activating polypeptide (PACAP) in the central nervous system of the frog Rana ridibunda. Journal of Comparative Neurology 324 485-489.

Received in final form 30 April 2002

Accepted 1 May 2002 